said to have been pierced three times by a vertical shaft. Yet the coals are not anthracite. The Vobster pits are very fiery. The Radstock pits, where the coal is horizontal, not so ; but they are worked in higher beds.

By reference to the Commissioner's report to Parliament, $187 \mathrm{I}$, it will be seen (p. $3^{8}$ ) in Mr. Prestwich's report on the Nettlebridge Valley coals, where Vobster is situated, that my recollections are confirmed; "bituminous coal" and "disturbed condition" being alike attributed to these coal beds.

With respect to the general question of the mechanical theory of earth-heat, I wonld respectfully refer $\mathrm{Mr}$. Lesley to my examination of the theory in the Philosopizical Magazinze for October, I875.

Harlton, Cambridge

\section{On the Origin of Certain Granitoid Rocks}

IN a paper by me "On the Pre-Cambrian Rocks of Shropshire," read before the Geological Society on the IIth inst., I call attention to certain granitoid and gneissic rocks in Primrose Hill, at the south-west end of the Wrekin. Associated with these metamorphic strata in such an irregular manner as to suggest an eruptive origin is a compact felspathic rock with minute quartz grains, which I at first presumed to be a quartz felsite. On submitting specimens to Prof. Bonney, F.R.S., for microscopic examination, he declared the rock to be clastic, and closely allied to the hälleflintas, which Dr. Hicks assigns to his Arvonian group. Certain observations recently made in south-west Shrop. shire, suggested to me a transition between the hälleflinta and the granitoid types, and, on communicating my suspicions to Prof. Jonney, he stated that a similar connection had been suggested by his microscopic examination. This morning I hammered over Primrose Hill foot by foot, and I have the satisfaction of announcing the fullest confirmation of our suspicions. In the same block, the compact bällefinta is frequently mixed up with granitoidite and hornblendic gneiss. In some cases, the metamorphism has taken place only near the surface, as if produced by atmospheric agencies; in others the crystallisation occurs in nests, while in others there is a gradual transition in mass from a compact to a granitic structure. This passage of bälleflinta into granite has obviously important theoretical applications.

Wellington, Salop, June 21

C. Callaway

\section{Migrations of Birds}

I NOTICED some time ago a communication in NATURE respecting this subject, stating that it would be instructive and interesting alile if naturalists would record any data they may have collected on this subject. For years now this matter has had my careful attention, and I therefore forward a few notes for the last two seasons, and also put forward the hope that observers stationed in other parts of the United Kingdom will contribute information of a like nature. I would also say that the weather noted applies to the night-the time, by the way, generally chosen for migratory movements.

\section{Vernal Migration, 1878}

Dates.
A pril 4 ... Gray Wagties. ing season. Weather clear, warm ing season. Weat
westerly breezes.

4 ... Tree Pipit $\ldots$... ... In full song and seen for first time

I5... Redstart ........ westerly breezes.

In full song in Encliffe. Wood and Rivelin Valley; warm westerly breezes, clear.

Derous, arrived curing Jast night.

I5 ... Ring Ousel ... ........ Numerous and full of song

I8... Chiffchaff In small rumbers, westerly breezes,

very warm, close.

fine and clear.

I9 ... Cuckoo $\ldots \begin{array}{llll}\text { fise and clear. } & \ldots & \ldots & \ldots\end{array}$ 22 ... Whitethroat ... ....... streets of Sheffield at $4.30 \mathrm{~A} . \mathrm{M}$.

22 ... Whitethroat ... $\ldots . .$. One heard; dull and misty drizzling $22 \ldots$ Martin and Sand rain, W.S.W.

Martin $\ldots$..... .3 in the Derwent Valley ... Blackan ........ in the Derwent Valley.

... W. W.S. 29 ... Whinchat $\ldots . . . \quad$... Seen for first time, weather dull, 29 ... Common Sandpiper ... Seen for

May $3 \ldots$ Landrail ${ }^{2} \ldots$... ... First heard, weather dull and gloony,

6 ... Spotted Flycatcher ... First seen, very wet night, wind direct, S. These birds are still solitary.
Vernal Migration, 1879

Dates. Species. Remarks.

Feb. 10 ... Song Thrush ... ... Arrived in night; dark and cloudy, , to ... Blackbird ... ... ... Arrived in night; dark and cloudy, March 20 ... Yellow Wagtail ... ... Numerous.

", 20 .... Wied Wagtlow Warbler .... .... One" specimen seen, somewhat feeble, ... Willow Warbler ... ... One specimen seen, somnew silent; wind $W$. by S., night dull and showery, snow only left ground and showery, snow only efown this species so early before. Ayerage species so early time being April 5 .

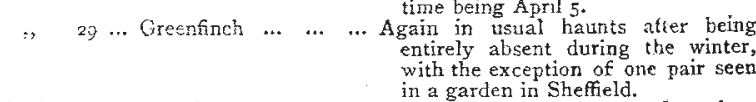

Apri] 9 ... Chiffchaff $\quad \ldots \quad \ldots \quad$... Saw and heard in young fir plantations at Hollow $\mathbb{M}$

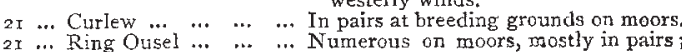

21 ... Ring Ouse\} ... ........ Numerous on moors, mostly in pairs 24 ... Tree Pipit ... $\ldots . .$. Arrived ; dull and showery weather, easterly winds

On the evening of $25^{\text {th }}$ not a bird was seen; on morning of 25 th the birds 26 ... Willow Warblers and abounded and their cheery notes are Chiffchaffs $\quad \ldots \quad$... $\mathrm{d}$.

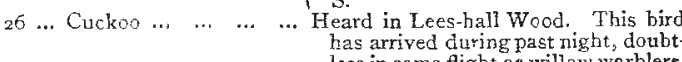
less in same flight as willow warblers, \&o.

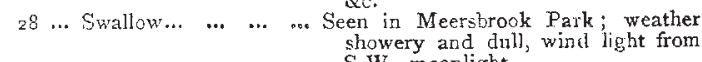

29 ... Whirichat ... $\quad \ldots \quad \ldots$ Seen in Meerstrook Park; weather showery and dull, wind light from S.E., mounlight.

May $\quad 2$... Wheatear …..... On muors, full of song. Rivelin and Redmires danis, in pairs.
7 his species has been here some few

$\begin{array}{ccccc}\text { This species has been here some few } \\ \text { 2 } & \text {... Redstart } & \text {... } & \text {... } & \text {... This bird bas now axrived, tut only }\end{array}$ his bird bas now arrived, but only
seen in small numbers. Cold easterly

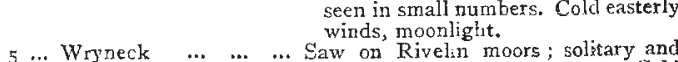
uttering its whistling notes. Cold easterly winds.

8 ... Landrail and White- $\begin{gathered}\text { Heard in meadows; very scarce; } \\ \text { probably came last night with a cold }\end{gathered}$ throat... ... ... $\quad . .\left\{\begin{array}{l}\text { probably came last ming } \\ \text { southnwesterly breeze. }\end{array}\right.$

22 ... Sand Martin... ... ... Skimming over the waters in small numbers. This species is remark

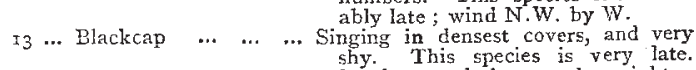

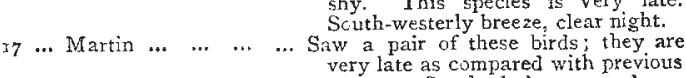
very late as compared with previous
ceasons. Scutherly treezes and very showery. 24 ... Swift $\quad \ldots \begin{array}{llll}\ldots & \ldots & \ldots & \text { One seen on the borders of the Rivelin } \\ \text { Moors. South-westerly breezes and }\end{array}$ very showery.

26 ... Spotted Flycatcher ... One specimen. $\begin{gathered}\text { veen, silent and seme- } \\ \text { what wary. N.W. by W., light, }\end{gathered}$ and showery mocnlight nigkt.

Such are a few extracts, taken verbatim, from my note-book; they might have been considerably increased, and the time of departure noted; as well as the arrival of our winter migrants, but I fear I have already trespassed too greatly on your valuable space. I sincerely trust that this interesting subject will be more fully discussed and studied by your correspondents and readers; for in that way many of the diffculties enshrouding the movements of the feathered tribes will be overcome.

Heeley, near Sheffield, June 9

Charles Dixon

\section{Glow-worms $\%$ Snails}

Your correspondent, Mr. R. S. Newall, has unconsciously reversed the natural condition of affairs in his note (NATURE, vol. xx. p. I97). The heading should have been as above. Glow-worms devour $\leq$ nails, which are their natural food. The particular snail in question had probably been attacked by one pat some of its phosphorescent matter glow-worms, which had lof casioned the idea that it was showing throtigh the body of the mollusk. Possibly in this case the snail may have proved too large for the glow-worm. An allied insect, Drilus favescens, somewhat rare in this country, and not luminous, is, so far as the female is concerned, seldom 
found excepting inside the shells of species of Helix, the animal of which it had pieviously devoured. R. MCLACHLAN Lewisham, June 27

Your correspondent, R. S. Newall, is upon the wrong tack, I think. His glow-worin was probably eating the snail, and not vice jersấ.

In Kirby and Spence's "Entomology" I read: "Snails give sustenance to Di:izus favescens, a bsetle, and its singular apte. rous female in the larva state, as well as to the larva of glow. worms." Is it not probable that the snme food snits the imago state of the insect?

I have often found glow-worms in suail sheils, and have always considered slugs and snails to be the natural food of the Lampy. ris noctilucs.

Bishopsteignton, Devon

R. Greentood PenNy

\section{Frogs and Glow-flies}

Mr. Netralt may be, perbaps, interested with the following extract from Damin's "Botanic Garden," Canto iv. p. x49, note :-

"In Jamaica, in some seasons of the year, the fire-fies are seen in the evenings in great abundance. When they settle on the ground, the bull-frog greedily devours them; which seems to bave given origin to a crrious, though crutel method of destroying these animals; if red-hot pieces of charcoal be thrown towards them in the dusk of the evening, they leap at them, and, hastily swallowing them, are burnt to death."

I was toid a few days ago of a cat which used to search for and eat glow-worms. It was suggested that she took thein for lights. GEORGE HINSLOW

\section{Intellect in Brutes}

THE following instance of sagacity in a cat has just been re. lated to me by a friend who knew both the cat and its owner well. The !atter, who lived at Ragusa Vecchia, in Dalnatia, was too poor to be able to provide food for the cat; the animal was thcrefore obliged to cater for himself, and was well known as a thief in the neighbourhood. One day one of the children was being sent ofi to school without any breakfast; the cat, hearing him sobbing for hurger, immediately went off, and retumed with a piece of breat he had stolen from a baker hard by, and brought it to the child. The same thing happened anotuer day, and be came back, dragring along a piece of meat bigger than himself. On crossing the threshold a bit of bone caught in a bole, so puss miawed till some one came to his help. This same cat, who was constantly catching birds on the roof, slept with some pet birds in a cage without attempting to touch them.

Ragusa, Aistria, June I8

Margaret Evans

I SEND you the following instance of intelligence in dogs :Last summer, wher on a visit at the château of my son-in-law, M. Sichart Wadington, Deputé, near Ronen, I had talen a wall in the grounds, accompanied by some of the family, and two favourite dogs, named respectively Minos and Rhadamanthus, followed the party, as usual, throughout the stroll. When nearing the hotse, on the return, my young grand-daughter rerrarked that Minos had lost his collar. The party came to a 1nalt, debating whether it was worth while to go back on a search. ing expedition, for the pleacure gronnds are somewhat exten. sive, and the cogs had been rambling away from the paths among lung grass. Both Minos and Rhadamanthus evidently seemed fo listen to the ciebate. It was clecided to make the search at a venture, ancithout saying a word to the dogs, the party commenced to retrace their steps. As a rule, these two dozs are inseparable; wherever the one goes, the other goes, and invariably the two follow any meinbers of the family when strolling about the place. At this juncture, however, Rhadainanthus, not having lost a collar, and having no special interest in the proposed search, went on her solitary way home to the stables but Minos kept with the party, walking on the gravel path-and this for some distance-when suddenly he took to the meadow, commenced ruming, and presently he was observed to stop and remain fixed with his head pointed downwards, partly buried in the tall grass. Naturally he was followed. The point of his nose was in contact with the collar! Could any child of man, under similar circumstances, have displayed more thoughiful sagacity than did each of the above dogs on the above occasion? The one thought she was not wanted, and having had enough play, wisely went home, whilst the other, thinking that his presence was requisite, wisely returned with the searching party.

When in Bute, some years ago, I heard from a gentleman, perfectly trustworthy, that a large Newfoundland dog, belonging to a friend of his, was observed one night by its ownei lying concealed under his bed-a strange circumstance, because the dog was forbidden to enter the house at night. The owner, being struck by this singular occurrence, resolved not to disinutb the creature, and, getting into bed, lept himself awake to watch events. It was not long before a sound was heard in the passage, a faint light was seen through the key-hole, the door opened, and instantly the dog flew from under the bed, and, springing forward, brought a man to the ground, the gentleman's own servant, who, accompanied by another fellow, was there for the purpose of robbery.

Vicarage, Monkwearmouth

HAVING read Mr. Peach's letter on "Intellect in Brutes," as shown by the sagacity he witnessed in his dog, I have been asked to send a similar anecdote, which I have often told to friends. Many years ago my husband had his portrait talien by T. Phillips, sen., R.A., and subsequently went to India, leaving the portrait in London to be finished and framed. When it was sent home about two years after it was taken, it was placed on the floor against the sofa, preparatory to being hung on the wall. We had then a very handsome large black and tan setter, which was a great pet in the house. As soon as the dog came into the room he recognised his master, though he had not seen him for two years, and went up to the picture and licked the face. When this anecdute was told to Phillips, he said it was the highest compliment that had ever been pair to him.

SOME years ago a fine arts exhibition was held at Dexby. A portrait of a Derby artist, Wright, was thus signalised: "The artist's pet dog distinguished this, from a lot of pictures upon the floor of the studio, by licling the face of the portrait."

Derby

HENRY CLARE

\section{Butterfly Swarms}

Wrxt reference to the swarms of butterflies referred to by $M$. Forel, in NATURE, vol. $x x . p .197$, it may be interesting to mention that Vanessa carla i is this year very common in the south of England. This butterfy is known to all English lepicopterists to be "periodical"-in some seasons it occu's in great numbers, in others-perhaps for several years in succession -not one specimen is to be seen.

Last season ( 1878 ) I saw no specimens, nor dia I hear of any about here. It seems, therefore-in such a bai season for insects as the present-impossible to consider the abundance of the species in England to be the result of "local fecundity." Whence, therefore, come these specimens? and is the periodical abundance of the species in Britain due to local causes or migration?

4, East Street, Lewes, July $x$

J. H. A. JENNER

\section{THE KILBURN SHOW}

$T T$ is difficult to estimate the disadvantages with which the Agricultural Exhibition at Kilburn has had to contend. So large a show must always be somewhat unwieldy, however skilfully planned, but the melancholy wet season has enormously increased the difficulties of arrangement, and we may add that iairly to study the implements and miscellaneous exhibits was quite impossible up to the time of our going to press. A few jottings set down at random concerning such instruments, opelations, and specimens as drew our attention while in the yard on Monday must suffice on the present occasion. Visitors were supposed to view the exhibits flom the avenues between the long rows of sheds; but these avenues, once grass, were transformed into roads of mud, in every condition of matter between the solid and liquid states. There were no paths across the sheds, and as most of the implements and other exhibits were not so arranged as to be approachable on more than one side, the difficulty of examining objects of interest was frequently insurmountable. 